\title{
Women's Roles in Adding Value to Wooden Crafts and Contributing to Family Income in Babung, Gunungkidul
}

\author{
Slamet Subiyantoro \\ Fakultas Keguruan dan Ilmu Pendidikan, Universitas Sebelas Maret Surakarta, Indonesia \\ Email: s.biyantoro@yahoo.co.id
}

\begin{abstract}
Gender discrimination continues to exist in the Special Region of Yogyakarta, with women often placed in the role of mother and housekeeper. In areas such as Bobung Village, where they form an integral part of the local industry, women transcend these roles to contribute to the economy. This research aimed to examine women's roles in adding to the artistic value of wooden crafts, their impact on increasing family income, and local community members' views towards these female roles. The research was socio-anthropological, with data obtained through in-depth interviews, participant observations, and content analyses of documents and records. Data were analyzed using an interactive model including data collection, reduction of presentation, and verification. The findings showed that (1) women play a significant role in improving the artistic value of wooden crafts through their batik painting and writing techniques. They make these crafts appear more exotic, and help to preserve traditional batik motifs. (2) With the addition of these women's motifs to wooden crafts, they add to their family income while still performing their domestic duties, such as caring for their children and cooking. Their wages are based on a daily system, collective system, or combination of both. (3) Batik-making on wooden crafts has feminine characteristics; it is soft and light, as opposed to woodworking's masculine characteristics of hard, physical work. Women's batik-making is consequently complementary to the work performed by men. According to the local people, there is no gender bias related to the job differentiation between men and women.
\end{abstract}

Keywords: family economy; income; women's role; wooden art and crafts

\section{INTRODUCTION}

Fitrianti and Habibullah (2012), Lestari (2008) and Kurniawan (2011) state that gender equality and the elimination of discrimination against women is prescribed in law. Moreover, the Convention on the Elimination of All Forms of Discrimination against Women was passed by the UN General Assembly in December 18, 1976. Indonesia already had provisions to protect women's interests, which include women's rights. Fundamental tenets included in the Convention's preamble is "The belief that the full and complete development of a country, the welfare of the world, and the peace effort requires maximum participation of women based on men and woman equality in every field" and "Women's contributions to family welfare and community development have been highlighted, but they have not been fully recognized". (Kurniawan, 2011).

Additionally, the US Ambassador at Large for Global Women's Issues Catherine M. Russell states that women's increasing participation in economic activities has been vital to improving the lives of their families and entire societies as well as their countries (Widiadana, 2013).

Despite the laws and international conventions, gender discrimination continues to exist in the Special Regional of Yogyakarta in central Java (Daerah Istimewa Yogyakarta - DIY) (Lestari and Dewi, 2010). A survey of a number of gender studies show that (1) women are only companions to men who are leaders of women, 
(2) the number of female teachers is higher, but more principals are male, (3) men enjoy a higher level access to information than women, (4) women are weaker during natural disasters because it needs not only physical strength but also endurance to face disasters, (5) women receive a lower wage than men's for the same work, (6) women are kinder than men, (7) The influence of male hormones during puberty, (8) mothers treat their male and female children differently (Lestari and Dewi, 2010).

The government has issued rules to remove all forms of gender discrimination but there are still other regulations that discriminate against women's within the family, in society and in the workplace. Kurniawan (2011), Lestari (2008), and Khotimah (2009) claim that gender discrimination can be found in every sector of the economy and this discrimination is both explicit and obeyed. The suggested discriminations are found in the Panca Dharma Wanita, which states (1) a woman is a wife and an assistant to her husband, (2) The role of women in marriage is in the home as a mother and housekeeper, in contrast to men whose role is as a husband, with rights to higher study as he wants and work a job as he wishes, etc. (3) When women get married they only have to do the duties of a house wife such as: cooking, tidying up the house, taking care of the baby, organizing the husband's finance. The five statements of women's duties, adopted by the Dharma Wanita organization, whose members are largely comprise women with spouses in the public service or Armed Forces. Lack the opportunity to improve their career although they have a good skill. (4) A woman is an additional breadwinner. The effect of these government-approved statements is to limit women's roles outside the family. According to Articles 31 and 34 of the Marriage Act, the husband is the household head and he is responsible to provide for his family. Therefore, a working wife is seen only have a role in earning extra income for her family. Even when women have similar qualifications to men, women will usually receive a lower salary. (Kurniawan, 2011).

It is obvious that women lack access to, and experience discrimination in the economy, despite holding the same qualifications. Their status is that of household companions. They do a lot of informal jobs which often require little expertise or skills, and usually do not have legal protection and appropriate remuneration, in addition to multiple tasks. Women are always viewed as the weaker gender and not accorded the same rights as men. Men also tend to give priority for higher education in the household. Men are the heads of households and the decision makers, while women are household companions and assistants, and not asked for their opinions. Women, unlike men, also tend to have multiple burdens as they work in both the public and domestic sectors. The abuse of women is both physical and mental and is evident in the data on domestic violence where women are involved as the victim of male abuse in $91 \%$ of cases while for men it is 9\% (Lestari and Dewi, 2010).

A number of studies have investigated the status of women compared to men, with a focus on politics, education, employment and law. Sugeng Haryanto (2008) from Merdeka University, Malang, entitled "Peran Aktif Wanita dalam Peningkatan Pendapatan Rumah Tangga Miskin: Studi Kasus pada Wanita Pemecah Batu di Pucanganak Kecamatan Tugu Trenggalek" ("Women's Active Role in the Raising of Poor Households' Incomes: A Case Study of Women Rock Crusher Laborers in Tugu Trenggalek District") analyzes the contribution of earnings of female rock crushers to family earnings, and the usage of earnings of female rock crushers. It finds that women who work as stone crushers make a significant financial contribution to family income. Indriani's (2005), Diponegoro University, paper entitled "Peran Perempuan dalam Perkembangan Industri Kecil (Studi Kasus: Perempuan dalam Industri Batik di Kabupaten Banyumas)" "The Role of Females in the Development of Small Industries (A Case Study: Females in the Batik Industry in Banyumas Regency)") discusses women's roles in the development of the batik industry in Banyumas. Nana Ristiana's (2013), Semarang State University, paper entitled "Perkembangan Peran Wanita dalam Industri Batik di Desa Bakaran Pati tahun 19771998" ("The Development of Women's Roles in the Batik Industry in Bakaran Pati Village 1977-1988”) discusses the work ethic of women workers in Bakaran Pati, the history of its batik industry and women's roles in the industry. Based on these previous studies a key research problem is: how do women perform the economic role directly related to wooden crafts?

Bobung Village in Gunung Kidul is a center for wooden crafts that employs many women, especially in the finishing process using batik-making techniques. This area of work is linked to the perceived nature of women as being very conscientious and more patient than men. This has led to a gendered division of work for women at this craft center. A consequence of this is the different wage levels between men and women found in a local socio-cultural context.

The reason for undertaking this research is there are many social problems that make women discriminated such as gender equality, women's emancipation, suppression, and status.

This study aims to analyze the role of women in 
improving the quality of wooden art crafts. It empirically evaluates this role of women in family economic improvement through their employment in the artisan industry and analyzes the views of local communities on women's roles in the gendered division of labor.

The research is intended to contribute to: the body of knowledge about women and their roles in enhancing wooden crafts value; understanding society's views in assessing the different roles in the division of work from a socio-cultural perspective, and; based on the results of this research, inform local government on policy formulation on women in relation to economic, social and cultural matters.

Art can be defined as work done by humans based on the senses and expressed through different media for a particular purpose. In the context of art crafts, the art objects are more about the practical function or functionality than art as a goal. In contrast to fine art, art is more on the purpose of art itself. Craft is a threedimensional art branch that has a practical application. Nonetheless, the object's functions created still require art support including a visual structure that is aesthetically pleasing to the users. Therefore, art crafts are commercial art because they are intended for other parties.

Various theories of gender used in this paper include Dirawan (2009), Nisa (2012), and Soeparman in Lestari and Dewi (2010), and Lestari (2008). These theories state gender equality in Indonesia is regulated in legislation. The Indonesian House of Representatives (DPR) has produced various legislation that can be said to be gender responsive (Dirawan, 2012).

The efforts to achieve gender equality in Indonesia is stated in the Outline of State Policy (Garis Besar Haluan Negara - GBHN) 1999 Act no 25 in 2000 on the national development program or Propenas from 2000 to 2004 and reaffirmed in the Presidential Instruction No. 9 Year 2000 on Gender Mainstreaming (in national development (Dirawan (2009); Lestari, \& Dewi (2010) ).

According to Soeparman in Lestari and Dewi (2010) and Silawati in Lestari and Dewi (2010), PUG is a strategy that is done rationally and systematically to achieve gender equality in a number of aspects of human life. PUG is done through policies and programs that takes into account the experience, aspirations, needs and concerns of women and men into the planning, implementation, monitoring and evaluation of all policies and programs in various fields of life and development (President or Presidential Instruction No. 9 of 2000). In the Presidential Instruction a whole range of executives such as the Governor, the Regent, and the Mayor must implement gender mainstreaming in all stages of development. In the development of women, women are placed as equal doers to men to gain access to, participate in, take control over, and profit from development. In principle, PUG places the individual as a whole person, democracy, equity, justice and equality (Lestari and Dewi, 2010).

PUG is a strategy that is done rationally and systematically to achieve gender equality in a number of aspects of human life through policies and programs that pay attention to the experience, aspirations, needs and concerns of women and men in the planning, implementation, monitoring and evaluation of all policies and programs in various fields of life and development (Presidential Instruction No. 9 of 2000). In the whole range of executive Instructions from the level of the Governor, the Regent, to the Mayor must implement gender mainstreaming in all stages of development (Lestari and Dewi, 2010).

According Harlianingtyas et. al. (2013) women's roles are a human resource that need to be empowered economically. Women tend to find it difficult to enter the labor market because of fears that permeate within the culture of the consequences should a woman leave her daily duties as a wife and housewife. A study of women's participation in economic activities is thus an important study because the number of women who engage in economic activity is a potential indicator of the social progress of a nation. An increasing of women's roles in economic activities is potentially one indicator of an enhancing of the position of women in society.

Gandarsih (1997) conducted research in the province of Yogyakarta on women's roles in economic activities. Despite the fact that women made up a greater proportion of Yogyakarta's population in the 1990s, their economic participation was not expressed. The potential of women has not been fully developed in terms of an improvement to their roles in the economy and hence contributing to the development of the country. They still remain largely in economically subordinate positions.

Improving women's roles and status is integral to and cannot be separated from national development. Therefore, efforts to increase the women's roles in development cannot be separated from (1) the effort to eliminate poverty (2) improving the quality of human resources as well as the quality of individual and community life, (3) increasing economic growth (4) achieving equity in the field of development and results of development, (5) increasing the active and dynamic role of the whole community, (6) the use of national stability and dynamic, and (7) sustainable and environmentally sound and future oriented development 
(Mubyanto, 1985; Gandarsi, 1997).

According to Suryadi (2001 in Fitrianti and Habibullah, 2012), if women and men have equal rights in education, then women will be able to participate more and have more leverage in their lives. Increasing the level of education then means an elimination of gender discrimination. The higher the educational level of women enhances human resources in the economy Better educated women are able to make their families healthier and provide better quality education to their children. Additionally, women with higher education have a chance to get better jobs. In contrast, women with a lower level of education will be more vulnerable to exploitation and less able to contribute to economic development (Harlianingtyas, 2013).

According to Putri et. al. (2009) women now have equality in education and employment so that although women have multiple roles in everyday life, where a woman can be a mother, a wife and as well as a worker, women still can realize their potential.

In domestic life, a woman's role is very important. Before equality in education and employment women's roles tended to be restricted to caring for and educating children. Nevertheless, this role is still an obligation that must be performed by women (Mulyawati, 1986; Putri, et al., 2009).

Along with rapidly changing economic and technological development, the position of women is also changing in many ways. Recently, women have gained the same opportunities to get an education and employment as men. This changed position can be seen in the number of women who currently have multiple roles, being a wife for her husband, a mother for her children and working in various fields or having a profession.

This research for this article was conducted in Patuk village, Gunung Kidul in DIY over a 12 months period using a naturalistic qualitative approach. The main data sources are taken from interviews with managers of wooden craft business, women employees, and local community leaders who understand the wooden crafts industry. The other data sources are places and events where wooden crafts are made. The last data sources are the documents and archives that are relevant to this research. The validity of the data is checked through triangulation techniques and informant reviews. The data analyses uses an interactive model which includes the stages of data collection, data presentation, reduction, and verification.

Based on the discussion above, the problem posed in this study is how women's roles in improving the quality of crafts impacts on family income.

\section{FINDINGS AND DISCUSSION}

\section{A Brief Description of Research Areas}

Gunung Kidul regency is located in the Special Region of Yogyakarta (DIY). The total area is $1,485.36 \mathrm{~km}^{2}$ of which $46.63 \%$ is mountainous terrain with many high peaks. There are eighteen districts and 144 villages in Gunung Kidul. It has much economic potential in sectors such as agriculture, fisheries, forestry, flora and fauna, industry, tourism and art crafts. Irrigation systems that rely on rainfed agriculture affect the growth of other sectors such as the handicrafts industry. One of the wooden craft industry centers in Gunung Kidul is Bobung village. Wooden art craft is one of the main established crafts in the village (Subiyantoro, et al., 2020).

Bobung village is inhabited by 128 families with 446 people that consist of 224 males and 220 females; the number of men and women is almost the same. Based on the demographic data of the village, the proportion of productive age is $63 \%$, children $25 \%$, and the elderly $12 \%$. Thus, the number of those of productive age is more than childen and the elderly. Approximately 91\% of the population are craft workers, the remaining of the population work as farmers $(6 \%)$, merchants $(2 \%)$ and others $(2 \%)$. The average works as a wooden art crafts men and wooden craft employees.

Included in wooden art crafts are various products such as mask, Loro Blonyo, plates, Menongan dolls, wipes containers, door wedges, and various other functional objects such as slippers, puppets, various animal crafts, etc. ${ }^{1)}$ Those wooden crafts come in various sizes from small to large. The craft materials used include pule and mahogany woods and to finish the crafts batik is used, both hand painted and stamped. These product are the most popular and more than 1500 units are produced every year. The government is supporting the development of an export marketing program with business and crafts people sponsoring promotional events both nationally and internationally. To make high quality products, it needs skillful crafts people who have a high level artistic skill in order to improve the craftmen's welfare and other workers'welare as well.

The family's function is to assist each other according to their portion, prior to use the women do simple jobs such as making batik, sanding or smoothing products. This work is possible because it does not disrupt women's primary work as housewives and can also be done in the home. These jobs also boost the family income (cf. Laily et al., 2020; Virgianita, \& Choiruzzad, 2018). 


\section{Women's Roles in Improving Wooden Art Crafts Quality through Batik Techniques}

Women artisans commonly work in wooden craft businesses, although the numbers of women are fewer than men. Given their widespread presence in these businesses, show that women's roles do make an important contribution to improve the quality of the art craft. A socio-cultural gender division in jobs can been demonstrated based on perceived gender characteristics and peculiarities.

Table 1 below shows that the number of women artisans is around $45 \%$ while the number of male artisans is about $55 \%$, that is the number of male artisans is ten percent higher.

Field observations show that the job types and descriptions for men and women are different, and is related to their differing expertise. The work of chopping wood, patterning, forming and making detailed parts of the craft are done by men. This job requires more physical strength than women, it is biological in character. This work is part of the production process because it needs physical strength and power.

Table 1. The comparison of the number of female and male workers

\begin{tabular}{|c|l|c|c|c|c|}
\hline \multirow{2}{*}{ No } & \multirow{2}{*}{ Business Name } & \multicolumn{4}{|c|}{ Number of Workers } \\
\cline { 3 - 6 } & & Male & $\mathbf{\%}$ & Female & \% \\
\hline 1 & Karya Manunggal & 7 & 70 & 3 & 30 \\
\hline 2 & Panji Sejati & 6 & 66.7 & 3 & 33.3 \\
\hline 3 & Asta Aulia & 15 & 78.9 & 4 & 21.1 \\
\hline 4 & Bayu Batik & 3 & 75 & 1 & 25 \\
\hline 5 & Bina Karya & 40 & 57.2 & 30 & 42.8 \\
\hline 6 & Vinda Batik Craft & 8 & 61.5 & 5 & 38.5 \\
\hline 7 & Bina Usaha & 7 & 63.6 & 4 & 36.4 \\
\hline 8 & Bina Karya & 6 & 66.6 & 3 & 33.3 \\
\hline 9 & Aneka Craft & 1 & 14.3 & 6 & 85.7 \\
\hline 10 & Hasta Karya & 30 & 66.7 & 15 & 33.3 \\
\hline \multicolumn{2}{|c|}{ Number } & 108 & 54.8 & 89 & 45.2 \\
\hline
\end{tabular}

The men's work is synonymous with the masculine gender as described by Dwiyanto and Yuwono (1999) in the following excerpt.

"Overall, the women's role in the traditional metal industry is still at a lower level than men. Many of the stages in the work needs strenuous physical effort as a result only the men are able to complete it. The type of work done by women in the traditional metal industry covers the light work".

("Secara keseluruhan peranan wanita dalam industri logam tradisional masih berada dalam tingkat yang lebih rendah dibandingkan dengan kedudukan pekerjaan pria. Banyak tahap pekerjaan yang memerlukan kerja berat/kasar sehingga hanya pekerjaan pria yang dapat menyelesaikanya. Jenis pekerjaan yang ditangani oleh kaum wanita dalam industri logam tradisional meliputi pekerjaan yang ringan" )

In other parts of production such as finishing, sanding, painting and writing batik are done by women artisans. This part is done after men artisans have finished working on their part of the production process. The finishing process requires industriousness, patience and a gentle touch associated with the character of women. The work of art crafts that is done by women in Bobung is thus synonymous with feminine traits.

The participation of women in the wooden art craft is significant, especially in terms of increasing the value of the aesthetic quality of these products. The role of women artisans is to beautify the crafts with painted and written batik techniques on on required parts of the product. According to one crafts person, both canting (melted candle wax) and brush batik techniques have been used since 1987 . Thus the techniques have already been 27 applied to improve the quality of art crafts by craft women.

Two informants, Mr. X (42 years old) and Mr. S, said that:

"For the wood batik craft work at Bobung hamlet, it cannot leave out the work of women, because it is women who can do that batik work, the mothers and girls. All this work could not be done if not for being helped by the women in particular to do the batik therefore a female workforce cannot be regarded as trivial."

("Nek babagan pekerjaan damel kerajinan batik kayu teng dusun Bobung niku mboten saged ninggalake pekerjaan wanito, amargi sing saged mbatik niku ibu-ibu utawi mbak-mbak. Sedoyo pekerjaan mboten saged rampung nek mboten di bantu wanita khususipipun mbatik dados tenaga wanita mboten saged dianggap sepele.")

The women's job of doing the written batik technique is commonly applied to wooden handicrafts. 
The advantages of using this batik technique are either to increase the products' economic value or to facilitate marketing, because the batik technique greatly appeals to consumers. The consumers feel pleased with the batik technique because it looks unique, attractive and is highly artistic.

The consequences of using this rather complicated technique adds significantly to its economic value. The products price increases because its quality is improved. The painted technique is also quite good as well, the technique needs less time than the written batik technique so the cost to make it is less. As a consequence the price is lower than the price of the written batik technique. Thus, the batik technique requires a higher level of skill, as well as extra charges and a longer time frame.

Batik techniques using brush and paint are a decorating for wooden crafts adds to its beauty. It affects both the economic value and the preservation of culture such as the preservation of Javanese batik motifs and underlying philosophical meaning. It can be seen in one of the craft products, Loro Blonyo. The part that is decorated with the batik technique is the object's surface. The female figure's surface that is decorated is the head using traditional Javanese hair-style, "the decoration of the forehead has a panunggul (a black semi-circle in the middle extending down from the hairline), then flanked by two pengapit (black triangular shapes with the apex pointing downwards), and flanked again by two penitis (two shorter, elongated black ovals. Below this there are the eyebrows, lips, skin and nails. The male figure's surfaces are decorated with hair, blangkon (a traditional Javanese head covering), eyebrows, and eyes.

The other parts that are decorated are accessories. Accessories on the female Loro Blonyo figure are the flower decorations on its bun, a flower arrangement, earings, necklace, and a belt buckle on the waist. The decorations on the male Loro Blonyo figure are the blangkon, keris (ceremonial dagger), clothing and jarik (the ankle-length wrap).

Loro Blonyo's clothing is decorated in the Basahan style (strapless batik wrap for the female and a waist wrap for the male) with isen - isen (the detailed working within the batik design) and setagen (waistband). Motifs that are often used for decorating batik and used in weddings and other ceremonies are Truntum, Sidomukti, Parang, and Kawung.. These Javanese classical motifs have a symbolic meaning found in Javanese philosophy and reflected in the Javanese view of life (cf. Subiyantoro, 2009).

Decorating the product is demanding work and is the preserve of women artisans. Decorating is the women's role in wooden art crafts that cannot be undertaken by the male. The type of work is closely related to feminine traits, the soul and the nature of the "feminine" such as industriousness, patience and a delicate touch. These traits have become a part of female traits that is constructed by culture. The brush and canting artwork seen in the decorating of wooden crafts is strongly influenced by these feminine traits.

Thus, women's roles in improving wooden crafts through batik techniques is very important. This is what one art anthropologist describes as a product of society's history that is imbued with socio-cultural values. Furthermore, art is a reflection of socio-cultural values and the subject of the author community (Coote and Shelton, 1992). Based on Javanese culture, batik is synonymous with women and woman is popular for Javanese Cultural Batik. From an anthropological perspective, Bobung Village is located in Gunung Kidul, in the province of Jogjakartatherefore the type of written batik is a Jogjakarta batik and the symbol of the 'Javanese philosophy' of the society in Jogjakarta.

\section{Women's Role in Improving Family Income}

The women's role in improving the quality of wooden art crafts as described above, concurrently increases the economic value of the product (cf. Steelyana, 2012). Despite the role of women of women in value adding to the product there remains a wage disparity between men and women. The difference in wages however, is likely related to levels of skill. The production process requires not only physical strength but also the ability to sculpt the required shape perceived as needing more skills, therefore it is a likely reason why men's wages are higher than than women who undertake the finishing process. Despite this differentiation, it is not regarded as an important issue for the women artisans. According to informants, the most important matter for women artisans is working in accordance with their expertise. "Modernization is a progress. It is a process to control materiality. It has purpose to increase a profit for personality" (Mulder, 1996: 58).

So in general, women artisans feel very grateful because despite perceived physical limitations and different skill sets they have been able to increase the family, in particular for married women. For those who are still in their teens they also feel happy, because they can save money, and also give to their parents to help out the family.

According to one informant, who is an experienced craftsman (Mr. J, 56 years old), to pay the workers he 
has been using minimum wage rates (regional minimum wage) mandated by the regional government. The daily salary (excluding the cost of providing three meals a day) for a woman is Rp25 000. A skilled female artisan is paid Rp30 000 per day along with three meals per day. This applies to artisans who do not stay at the business owner's home. For artisans the cost of eating is never taken into account because they are considered family. In addition every day they are also given free snacks with coffee and sweet tea.

"In today's world, women are not only housewives but also outside workers. It is referred to as the development of women's dual roles: on one hand, she must stay at home to care for her child, while on the other, she must work to provide for her family's needs." (Tilly and Scott, 1978). Therefore, If the three free meals a day are included then it amounts to a supplement of Rp15,

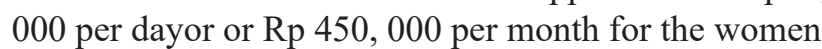
artisans who work in their employer's workplace. It means that, women artisans gain an additional economic benefit from the business owner. If the economic value is calculated, female artisans had also contributed more.

Women artisans receive an average daily wage of Rp750 000. Work is also done at home under what is called the borongan system, that is piece rate work with remuneration based on output rather than time therefore the greater the production, the larger the payment. The payment under this system is $\mathrm{Rp} 750$ to $\mathrm{Rp} 1000,000$. It means that in one month a female worker can increase her income by Rp500 000, according to one business owner. Thus in one month women artisans can receive a salary of around Rp1 250000 . According to informants, women artisans with high level skills can receive on average a wage of Rp 1500000 per month, assuming a monthly wage of Rp1 000000 plus a borongan payment of Rp500 000.

From the above calculations, every women artisan can receive between Rp1 250000 to Rp1 500000 per month. However, this remuneration is not necessarily matched in all the Small to Medium Business Enterprises (Usaha Kecil Menengah - UKM). Some women artisans are collaborating with the Pekerti Foundation from Jakarta which acts as a foster organisation. The Foundation is always booked at international standards prices and then exported, but they also require employees to be paid a reasonable wage.

In this way the income earned can improve the welfare of the family. Especially it can add to the husband's income if he is working, whereas for the husband who is not working it can be the sole source of income for families. "Women employees with young children often need assistance in balancing the conflicting demands of work and family. In response to this welldocumented problem" (Fernandez, 1986: 37).

Data collected from the Field research shows that husbands of women artisans work in the same field but in different workplaces.

Table 2. The Comparison of Male and Females Artisans monthly Wages

\begin{tabular}{|l|l|l|}
\hline \multirow{2}{*}{ Classification } & Wage & \\
\cline { 2 - 3 } & Male & Female \\
\hline \multirow{2}{*}{ Daily } & $\mathrm{Rp} \mathrm{1,050,000-Rp}$ & $\mathrm{Rp} \mathrm{750,000-Rp}$ \\
& $1,250,000$ & $1,000,000$ \\
\hline \multirow{2}{*}{ Borongan payment } & $\mathrm{Rp} \mathrm{750,000}$ & $\mathrm{Rp} \mathrm{500,000}$ \\
\hline \multirow{2}{*}{ Total } & $\mathrm{Rp} \mathrm{1,800,000-Rp}$ & $\mathrm{Rp} ? 1,250,000-\mathrm{Rp}$ \\
& $2,000,000$ & $1,500,000$ \\
\hline
\end{tabular}

The table shows that there are different wage levels. However, the wage differences do not influence the work quality. The craft women said that they work happily because they can finish the job while sharing and chatting with other craft women. "The most common problem that women face is the wage disparity between men and women as a result of their low skill and education as a result of patriarchy culture." (Ester, 1984).

"Ms. S (37 years) said that "I can finish my work while I relax and talk to my friend Ms. Tr (40th ) who has the task a to apply a white coat of paint, Ms. End (27 th) and Ms. Sih (31th) have the task of painting on the batik, Ms. Y (25th), and Ms. Mar (21th) who have the work of doing the finishing of the batik spending the evening on the handcrafts".

("Ibu S (berusia 37 tahun) ngendiko "kulo saget ngerampungake gawean kulo kalian nyasante, ngobrol kalian rencang kulo ibu Tr (40 th) sing tugase ngecet dasaran warna puti, ibu End (27 th) lan ibu Sih (31 th) sing tugase mbatik, ibu Y (25 th), lan ibu Mar (21 th) sing tugase finishing bating mbuang malam teng kerajinan".)

The economic role fulfilled by women artisans is very meaningful for the community of Bobung village with its kinship system based on patrilineal lineage. Because the system is patrilineal or patriarchal, women are not actually placed in a dominant economic role in the family. Nevertheless, the income earned each month by the women does have significant economic meaning 
for the family. The family's income increases and so improves the welfare of the family, especially to meet its daily needs.

Finishing skills and women artisan's abilities is not related to educational attainment. The educational attainment of women artisans' average is still low. The data collected reveals that $6 \%$ are uneducated, $5 \%$ have not completed elementary school, $1 \%$ graduated from kindergarten, $45 \%$ graduated from elementary school, $24 \%$ gradusted from junior high school, $8 \%$ graduated from high school, $1 \%$ graduated from a three year degree, and $1 \%$ gaduated with a bachelors degree. The lack of education may also have an impact on a lack of understanding of the political field, knowledge, and concern for the environment and health. However, the finishing skills of batik are not directly related to education. As affirmed by a woman artisan, Mrs. T (34 years), batik does not require a diploma of higher education, but what is important is batik expertise, with batik expertise, the value-adding to the product is very significant. "In some workplaces, women are designated to lower-level positions. This trust will approve the difference that has occurred since they were born to distinguish their ability" (Ester, 1984).

The above discussion shows clearly that women's economic roles in improving the family income cannot be underestimated. The data shows women have a wider role than staying at home but by working also increase family income. It means that the position of women cannot be judged as being inferior to men. Equal opportunities in the workplace can encourage women to gain an equal position in adding to family income.

\section{The Local Communities' Views on the Division of Work in the Art Crafts Industry between Men and Women}

In Bobung village, women's roles in general are not limited to domestic roles which include cooking, washing, and caring for children. Women leave the house to work on crafts for a living in accordance with their ability. Their work in wooden art craft are primarily sanding and batik painting. Men's work includes wood cutting, shaping the wood and making detailed of the craft. In this case it appears that women are more likely to do the finishing work. It is clear that the women's role is not part of the production phase but their role is important because it leads to a rise in the value of the arts but also the the economic value of the product. It means that the women's role is not only in the household and earning a living but also to preserve culture in this case wooden art crafts.
The views of informants, both men and women about women's work in sandpapering and batik finishing, is neither due to restricted activity, nor because of discrimination. In the community the type of work done by women is seen as being in accordance with the perceptions of the biological and psychological nature of women and their feminine characteristics. So far the assumption in the research conducted based on western culture values is that the division of labor inthe industrial sector and in agrarian society direct women toward domestic work.

It is generally recognized that men's role is as the breadwinner in the family and is also the leader in the household. Therefore men's role is dominant and women's role is subordinate, causing discrimination. This view however, does not hold for the people in Bobung village, grouping the jobs by gender actually is a positive thing because they complement each other. The role of child care is often performed by the husband or father, when the wife is working, likewise the husband also helps the wife cook and wash.

There are many women can be very good housewifes (cooking and parenting) as well as being good artisans. In practice women can take children to the workplace, or when they pick their children up from school they ask for permission to absent for a brief period. In fact, at different times there are women who will a take work home so that they can also do cooking, washing and care for their children that is, also perform their role ashousewives. In this case women have multiple roles of caring for children and earning a living.

Local community socio-cultural views about the differences between men and women jobs in craft making is positive. What women do in improving the quality of the crafts by sanding and batik painting is not considered as inferior work to the men's jobs. Sculpting the form of the art craft,done by the men, is also not recognized as the preeminent job. However, all of these jobs are recognized as steps that must be done to make the craft.

The assumption in discriminatory behavior toward women is it that it leads to marginalization in the workplace and women are shifted to the periphery and removed, because they are considered less skilled; however, this was not found in Bobung Village. Moreover, the feminization presence of politics or the segregation and separation between men's job and women's was also not evident. According to the informants, the men's work is based on the trait of strength in line with trait and soul of craft artists. Thus community view toward the differences of men's job and women's job are not seen as a segregation but valued as co-existing and complementing each other.

The community did not judge women's jobs in 
finishing, like sanding and batik, as a stigma. Society in fact considered thedivision of jobs asdue to the process of identifying everything that is suitable for women's trait formed by the socio-cultural environment. During this time, the various socio-cultural processes resulted in received women's traits and the identification of what are determined as matching jobs.

Employment and wage differences in the context of craft art are inseparable with the local community's value system. These values are very important because as they shape its understanding or meaning. The Javanese values found in Bobung village is certainly very different to other cultural values or western cultural values. Because the socio-cultural construction needs a collective consciousness to embed its values within a religious context and for the achievement of worthy human goals. The community's view is that the complementary work, which has fallen to men and women in craft making, is received as a grace. This view is reflected in the informant (Mr. Tkn, 60th) with the statement of

"There is no difference in the work of a male and female. Because in all it is in oneself and is in accordance to the field and what is a perfect fit with traits or character also ability. To the contrary of being rather different it is a thing that is one and a one that can make complete as a result becomes complete".

"Boten wonten bentenipun pakarya estri lan jaler. Amarga sedoyo niku sampun kiyambak-kiyambak lan sampun sesuai bidang lan sampun trep kaliyan sifat utawi watak ugi kemampuanipun. Malah kapara benten puniko setunggal lan setunggilipun saged nglengkapi sahingga dados jangkep".

The above discussion confirms that the concept of Javanese philosophy is synonymous with social harmony and its culture has contributed greatly to the formation of character and the traits of their peoples. The balance of men and women is also shown in the dualism of Taoism which basically merges with each other, complements each other, and does not judge the value of others... Thus the Bobung's community view that represents Javanese culture is very relevant to the philosophy of harmony consonant with the Islamic concept of assessing between men and women as being the same except in matters of their charity and piety. The statement asserts that batik work is noble as a means of practice and as part of women's position in completing tasks that men are responsible for.

\begin{abstract}
"The main difference between man and woman's productivity grows when man becomes a special producer of agriculture and non-agriculture or service. Beside, woman only produce traditional product and service for family's necessities. A special producer has a long time to do skill training more than a traditional producer" (Ester, 1984: 215).
\end{abstract}

\section{CONCLUSION}

Based on the research results and discussion, it can be concluded that (1) women's role in working on the aesthetic aspects of wooden crafts improves the quality of their artistic value through the women's written batik and painted batik techniques. In this role, they not only add beauty and attractiveness to various craft forms, but also preserve the value of Javanese culture, such as the classical motif of batik. (2) Women in Bobung Village play an important role in increasing their families' income. Technically, the skills of women in finishing batik can provide millions of rupiah. This income makes a significant addition to the family income, but without them having to leave their domestic roles, such as caring for their children and other domestic work, because batik work can be taken home. (3) Local society views the women's finishing work on batik craft as an essential complement that cannot be separated from men's work. This means that the differences in the type of work are seen as complementary rather than having a different status. This research further showed that more attention should be paid by business owners to the health of their workers, especially women batik artisans, because they are vulnerable to contracting lung disease and thus need masks. This paper has not been able to explore occupational health and safety issues but in the course of research, it was identified that dust and chemicals pose a hazard for female workers. There is a need for further research research on how women's health impacted by the making of batik wooden crafts.

\section{ENDNOTES}

1) Loro Blonyo are a pair of wooden statues of a Javanese couple in traditional dress. Menongan dolls or menong is a statue which means beautiful woman, olive skin, small lips, long eyebrows, and on the head there is a crown resembling a cigarette or a crown. 


\section{REFERENCES}

Boserup, Ester (1984). Peranan Wanita dalam Perkembangan Ekonomi. [The role of Women in Economic Development] Jakarta: Yayasan Obor Indonesia.

Coote, J. \& Shelton, A. (1992). "Art Aesthetics". In Anthropology Art and aesthetics (Coote, J\& Shelton, A). New York: Oxford University Press, Inc. pp. 1-11.

Dirawan, G. Darma. (2009). Konsep Sibaliparri Kesetaraan Gender Dalam Pengelolaan Lingkaran Masyarakat Mandar. [Sibaliparri's Concept of Gender Equality in the Management of the Mandar Community] Bunga Wellu, 14(1), 45-54.

Dwiyanto, D., Yuwono, J., \& Edy, S. (1999). Peran dan fungsi Wanita dalam Industri Logam Tradisional di Yogyakarta dan Jawa Tengah: Studi Etnoarkeologi. [The Role and Function of Women in the Traditional Metal Industry in Yogyakarta and Central Java: An Ethno-archeological Study]. Humaniora, 12(1), 4955.

Fitrianti, R. \& Habibullah. (2012). Ketidaksetaraan Gender dalam Pendidikan Studi pada Perempuan di Kecamatan Majalaya Kabupaten Karawang1 [Gender inequality in Education; Study of women in Majalaya District, Karawang Regency). Sosiokonsepsia (17) 01, 85-100.

Gandarsih, T. (1997). Peran Wanita dalam Kegiatan Ekonomi (suatu studi kasus mengenai peran wanita pembuat tempe di Desa Plembutan, Kecamatan Playen, Kabupaten Gunung Kidul, propinsi Daerah Istimewa Yogyakarta. [The Role of Women in Economic Activity (a case study about women's roles as tempe makers in Plembutan Village, Playen District, Gunung Kidul Regency, Yogyakarta Special Region Province) Humaniora, V(2), 125-134. doi: https://doi.org/10.22146/jh.1904

Harlianingtyas, I., Kusrini, D. E., \& Susilaningrum, D. (2013). Pemodelan Partisipasi Wanita dalam Kegiatan Ekonomi Rumah Tangga Nelayan di Pesisir Timur (Studi KasusKecamatan-Kecamatan Bulak Mulyorejo dan Kenjeran. [Modelling of Women's Participation in Fishing Household Economic Activities on the East Coast (A Case Study of the Bulak, Mulyorejo and Kenjeran Districts) JURNAL SAINS DAN SENI POMITS, 2(1), 2337-3520.

Haryanto, Sugeng (2008). Peran Aktif Wanita dalam Peningkatan Pendapatan Rumah Tangga Miskin: Studi Kasus pada Wanita Pemecah Batu di Pucanganak Kecamatan Tugu Trenggalek. Jurnal Ekonomi Pembangunan, 9(2), 216-227.

Indriani. (2005). Peran Perempuan dalam Perkembangan Industri Kecil (Studi Kasus: Perempuan dalam Industri Batik di Kabupaten Banyumas). Thesis,
Universitas Diponegoro, Semarang.

Khotimah, Khusnul (2009). Diskriminasi Gender terhadap Perempuan dalam Sektor Pekerjaan. Jurnal YINYANG, 4(1), 58-180.

Kurniawan, N. (2011). Hak Asasi Perempuan dalam Perspektif Hukum dan Agama. Jurnal Konstitusi, $I V(1)$, 153-174. From: http://publishingwidyagama.ac.id/ejournal-v2/index.php/jk/article/ download/304/299

Laily, Triyonowati, Wahidawati, Asyik, N.F., \& Sukaris (2020), Innovative Behavior To The Success Of Women Entrepreneurs Of Indonesian Batik, International Journal of Scientific \& Technology Research, 9(6), June 2020, pp. 704-707

Lestari, P. \& Dewi, M. Astuti. (2010). Model Komunikasi dalam Sosialisasi Pengarusutamaan Gender dan Anggaran Responsif Gender di Provinsi Daerah Istimewa Yogyakarta. Jurnal Ilmu Komunikasi, 8(2), 191-203.

Lestari, Y. (2008). Persepsi dan Partisipasi Anggota DPRD Propinsi Daerah Istimewa Yogyakarta terhadap Kesetaraan Gender. Thesis, Universitas Diponegoro.

Lundy, Marta (1995). Empowering Women in the Workplace. New York: The Harworth Press.

Nisa, Chairun (2012). Pentingnya Payung Hukum Kesetaraan Gender. Last Updated on Tuesday, 27 November 2012 11:59 Written by icmijabar fromhttp://icmijabar. or.id/uncategorized/pentingnya-payung-hukumkesetaraan-gender/ (diunduh 26-02-2014, 20:34).

Putri, P. S. \& Respati, W. S. (2009). Makna Hidup pada Perempuan Dewasa yang Berperan Ganda. Jurnal Psikologi, 7(2), 63-71.

Ristiana, Nana (2013). Perkembangan Peran Wanita dalam Industri Batik di Desa Bakaran Pati tahun 1977-1998. Thesis, Univeristas Negeri Semarang.

Subiyantoro, S. (2009). Patung Loro Blonyo dalam Kosmologi Jawa. Humaniora, 21(2), 162-173. DOI: https://doi.org/10.22146/jh.1327

Subiyantoro, Pujiyono, Kristiani, Maryono, D., \& Wijaya, Y.S. (2020). Cultural Enculturization in the Art of Masks: A Case Study of the Industrial Enterprise of Batik Kayu, Bobung, Patuk, Gunung Kidul, Yogyakarta. Budapest International Research and Critics Institute (BIRCI-Journal): Humanities, 3(4), (2020), DOI: https://doi.org/10.33258/birci. v3i4.1400

Steelyana W.E. (2012). Batik, A Beautiful Cultural Heritage that Preserve Culture and Support economic Development in Indonesia. Binus Business Review, 3(1), May 2012:116DOI: 10.21512/bbr.v3i1.1288

Usman, S. (2004). Pembangunan dan Pembaerdayaan masyarakat. Yogyakarta: Pustaka Pelajar

Virgianita, A. \& Choiruzzad, S.A. (2018), Indonesia's subnational competitiveness and preparedness for 
ASEAN economic community 2015: Mapping literatures, in Competition and Cooperation in Social and Political Sciences - Adi \& Achwan (Eds) $@ 2018$ Taylor \& Francis Group, London, https://staff.ui.ac. id/system/files/users/herdis/publication/639549ilovepdf-compressed.pdf
Widiadana, Rita A. Women's Economic Role Vital to National Development. The Jakarta Post. Retrieved on 13 September 2013, from http://www.thejakartapost. com/news/2013/09/13/women-s-economic-rolevital-national-development.html. 